TRANSFORMING THE CONSTRUCTION SECTOR: AN INSTITUTIONAL COMPLEXITY PERSPECTIVE

\begin{tabular}{|r|l|}
\hline Journal: & Construction Innovation: Information, Process, Management \\
\hline Manuscript ID & CI-04-2021-0071 \\
\hline Manuscript Type: & Research Article \\
\hline Keywords: & $\begin{array}{l}\text { BIM, Construction Engineering Management, Construction Technology, } \\
\text { Innovation, Open Manufacturing/Offsite Construction, Construction } \\
\text { Management }\end{array}$ \\
\hline \multicolumn{2}{|l}{} \\
\hline
\end{tabular}




\title{
TRANSFORMING THE CONSTRUCTION SECTOR: AN INSTITUTIONAL COMPLEXITY PERSPECTIVE
}

\begin{abstract}
Purpose: Government initiatives to improve construction have increasingly become more focused on introducing a repertoire of technologies to transform the sector. In the literature on construction industry transformation through policy-backed initiatives, how firms will respond to the demands to adopt and use innovative technologies and approaches is taken for granted, and there is scarcely any attention given to the institutional implications of transformation agenda.

Design: Following a synthesis of literature on the UK's industry transformation agenda, we use the concepts of institutional logics, arrangements, complexity and strategic responses to suggest seven research questions that are at the nexus of policy-backed transformation and institutional theory.
\end{abstract}

Findings: In this paper, we argue that increasing demands for the adoption and use of digital technologies, platforms, manufacturing approaches and other 'industry-4.0'related technologies will reconfigure existing logics and arrangements in the construction industry, creating a problem of institutional complexity for general contracting firms in particular.

Originality and Value: The questions are relevant for our understanding of the nature of institutional complexities, change, strategic firm responses, field-level dynamics and implications for the construction industry in relation to the transformation agenda. This paper is positioned to spur future research towards exploring the consequences of industry transformation through the lens of institutional theory. 
Keywords: Construction industry transformation, digitalisation, manufacturing, institutional logics, change, complexity, strategic responses, general contracting firms

\subsection{INTRODUCTION}

The global construction industry is constantly berated for low productivity, delayed projects, a slow work pace, unsafe work practices and for delivering projects that exceed planned costs (Buehler, Buffet and Castagnino, 2018; Laubier et al., 2019). These problems are partially attributed to the industry's lack of innovation, fragmentation arising from its configuration as a complex product system (Winch, 1998) and reluctance to embracing modifications that will impact established ways of organising work within and between firms (Hall, Whyte and Lessing, 2020). As part of attempts to tackle the problems of the construction industry, which are typically associated with conventional well-established norms and preferred practices (Winch and Maytorena-Sanchez, 2020), increasing attention is being given to promoting a widespread use of a raft of digital technologies, manufacturing and platform-based approaches, 3D printing, analytics and big data, digital twins, sensors, machine-to-machine communication and $\mathrm{AI} /$ machine learning (Duong Oesterreich and Teuteberg, 2016). These developments are usually alluded to the idea of a 'fourth industrial revolution' in construction (construction 4.0) (Boton et al., 2020) - a concept that remains a source of contention (Chan, 2020; du Plessis and Sherratt, 2020).

The growing focus on the introduction and integration of advanced data-centric, digital and automation technologies and manufacturing approaches into the construction industry has drawn attention in policy, practice and academia (Dallasega, Rauch and Linder, 2018; Mariani and Borghi, 2019). It has led some to suggest that the developments are akin to what 
is called the 'fourth industrial revolution (4IR)' or 'industry 4.0' mainly in manufacturing (Reischaeur, 2018; Li, 2018), thus coining the term 'construction 4.0' (Boton et al., 2020; Sawhney, Riley and Irizarry, 2020), whilst others question whether the drawing of such parallels is merely rhetoric (Chan, 2020; du Plessis and Sherratt, 2020). Although arguments about the appropriation of industry 4.0 in the construction industry remain unresolved among researchers, there is some convergence about the benefits that digital technologies, automation, platformisation and manufacturing approaches can bring. A widespread adoption and use of these hosts of technologies by actors in the construction sector are reported to hold the potential to unlock hitherto unrealised significant productivity gains, enable more accurate forecasting, planning and decision making and investments (Buehler, Buffet and Castagnino, 2018; Ribeirinho et al., 2020). Furthermore, forecasts suggest that by $2023,50 \%$ of major enterprises will be using digital twins to support the management of their portfolio of built assets, monitor behaviours of end users in order to inform how their future assets might be built for greater user experience. This is important for producer and asset owners, given that customer-centric business operations are increasingly becoming valuable in a society that is growing more connected (cf. Frank et al., 2019). Whilst industry stakeholders in manufacturing are reported to have already started reaping gains from 'industry 4.0' (Reischauer, 2018; Xu, Xu and Li, 2018; Bag, Gupta and Kumar, 2021), those involved in the construction industry (e.g., clients, contractors, consultants, end-users) are yet to realise the gains that these advanced technologies and approaches are espoused to deliver.

Like every other large-scale reform agenda in construction, realising any of the visions espoused in reform policies will be attendant with crucial changes to the way the industry is organised, its existing structures, values, beliefs, practices and norms. Put differently, the 
materialisation of the policy visions of a transformed construction industry will be accompanied by an institutional change (Micelotta, Lounsbury and Greenwood, 2017). Accounts of how such changes occur, as well as their implications, are highlighted in studies including Bag et al. (2021) for the adoption of big data analytics powered by artificial intelligence for sustainable manufacturing in South Africa; Rasmussen, Jensen and Gottlieb (2017) in exploring benchmarking innovation policies in the Danish construction industry; (Winch and Maytorena-Sanchez, 2020) in exploring how large scale projects are used as a tool to drive institutional changes in a complex field like defence acquisitions, and (Hetemi et al., 2020) who examine the dynamics of institutional field changes and their influence on large scale projects (highspeed rail) and the management of organisations involved. Across these studies, and others in the mainstream management literature (e.g., Greenwood et al., 2011; Thornton, Ocasio and Lounsbury, 2013; Micelotta et al., 2017; Ocasio, Thornton and Lounsbury, 2018), it is evident that grand-scale transformation agenda always seek to establish change by reconfiguring institutional arrangements (i.e., logics), with knock-on effects for how actors operating in an institutional field might respond (Oliver, 1991; Pache and Santos, 2010).

Ongoing government-led construction industry transformation initiatives in UK is one of such grand-scale change seeking agenda (Sergeeva and Winch, 2020; Winch and Maytorena-Sanchez, 2020; Ernstsen et al., 2021). Indeed, the government, for several decades, has been identified as a notable actor able to trigger changes in the industry through the implementation of policy-based agenda prioritising management-focused changes and gel the industry together by promoting collaborative practices (Latham, 1994; Egan, 1998). This has given way, in more recent times, to more technology-centred initiatives incorporating a mix of coercive and voluntary measures (Dainty et al., 2017). Across government policy, 
there is now a strong focus on implementing changes to the ways capital works projects (e.g., bridges, highways, buildings) are designed, procured, constructed, operated and maintained (IPA, 2016; HM Government, 2018). Central to this focus is promoting a widespread use of digital technologies (e.g., BIM), manufacturing approaches, platforms and digital twins in the creation and maintenance of the country's-built environment. Now, digitalisation techniques, manufacturing-based approaches, and whole-life asset performance considerations have been placed at the forefront of the government's reform agenda outlined in Government Construction Strategies (Cabinet Office, 2011; IPA, 2016) and Industrial Strategies (HM Government, 2013, 2018). The 2016 BIM mandate, for instance, made it compulsory for all public sector projects to be delivered using BIM (IPA, 2020), triggering a gradual - albeit slow - shift of the construction industry towards the use of more digital tools in the design and delivery of construction projects (NBS, 2020; Zomer et al., 2020). Sergeeva and Winch (2020) highlight this strong focus in exploration of how project-based firms in the UK respond to the Government's narrative of innovation, and Ernstsen et al. (2021) also emphasize a similar point in exploring how innovation champions can create visions for transformation based on these same narratives. The Construction Playbook, recently published by the government, outlines how public sector procurement is going to be used to push for the adoption and use of these 'transformational' technologies in the industry (HM Government, 2020).

Transforming the construction industry by promoting advanced digitization, manufacturing, automation of processes, data-centricity, information and communication technologies, virtual / augmented realities will reconfigure how the sector operates (cf. Gann et al., 2000; Yoo et al., 2012). Processes of planning, design, construction, supplier network management, stakeholder engagement, communication, funding acquisition, recruitment and 
training are part of aspects of organising and project delivery in the industry that will undergo transformation (Fitzgerald et al., 2013). Already, project designs and inter-disciplinary communications are being conducted in digital environments, model-based design and component manufacturing approaches, AR/VR training techniques and data-led analysis for designed and built assets are increasingly being used to replace conventional techniques in project delivery (Dallasega, Rauch and Linder, 2018). These developments are gradually changing existing configurations, normative practices and shared understandings in the construction industry. It follows that techno-centric industry transformation initiatives are gradually triggering institutional changes though an introduction of its unique institutional logics which consequently place different demands on firms. With the transition from the status quo to a 'transformed' construction industry that defined by extensive uses of digital technologies, twins and data, manufacturing approaches and platforms, the co-existence of two potentially conflicting institutions with dissimilar logics placing different demands on actors (e.g., clients, manufacturers, contractors, lenders, regulators, legislators, professional associations and training establishments). The actors will thus be faced with a problem of conflicting logics - to which they have to respond - throughout the transformation period, presenting to them what is termed a problem of 'institutional complexity' (Micelotta et al., 2017). The impacts of these changes are going to be directly experienced by firms that are actually involved in the execution of projects. However, the way the impacts of the changes will be felt in such firms is not a passive activity as firms, in the form of actors operating in an institutional field, have self-interests at play and so might not simply comply, as often assumed in studies that examine industry responses to government policy demands using institutional theory (e.g., Bag et al., 2021).

Given the increasing attention to industry transformation in policy and academia, it is 
rather surprising that there is scarcely any attention to how the envisioned changes will present an institutional quandary for actors operating in the sector, who would have to implement response strategies in order to survive or thrive under the new 'order'. This paper contributes to the discourse on industry transformation through a critical conceptual argument around institutional complexities that would specifically confront general contracting firms (GCFs) in the construction industry as technocentric policy-backed changes are implemented mainly in the UK's field of public sector construction. The goal is not to argue against the improvements construction transformation and its repertoire of techniques and technologies will bring to an industry often berated for poor productivity, delayed projects, a slow work pace, unsafe work practices and for delivering projects that exceed planned costs. Rather, we offer a counterbalance to ongoing debates about construction transformation by critically examining the potential implications the impending reforms hold for construction firms, how that could be counterproductive to ongoing government-led efforts and setting out directions for future research that calls on researchers to critically analyse industry transformation through the lens of institutional theory. To this end we synthesize literature about ongoing construction transformation agenda in the UK and draw the concepts of institutional logics, institutional change (Micelotta et al., 2017), institutional complexity and strategic responses (Oliver, 1991; Pache and Santos, 2010) to critically assess how GCFs, in particular, might respond to the pressures to be encountered based on demands that construction transformation would inevitably present to them.

An important point of departure is the consideration of firms as the unit of analysis as they are the focus for sector wide changes, instead of projects. Specifically, the analysis focuses on general contracting firms (GCFs) because they are key operatives sitting at the nexus of the multidirectional pressures that will arise from the demands of industry 
transformation. GCFs are typically involved in the actual delivery of projects and therefore key agents of change implementation through the approaches, tools and techniques deployed. We avoid an analysis of all industry stakeholders/institutional actors (e.g., clients and the entire project supply chain) in the paper as they all possess different structural, strategic positioning, influencing and operational features that would make a lumped-up evaluation of their potentially varied responses rather complex. To provide an analysis of other key stakeholders is thus outside the remit of this paper's focus. We situate our critical discussion in the context of a moderately centralized, highly uncertain and competitive field of public sector project delivery in the UK. Our theoretically informed discussion is positioned to broaden the scope of ongoing research about construction industry transformation from focusing on mostly technical dimensions (e.g., Oesterreich and Teuteberg, 2016; Pasetti Monizza, Bendetti and Matt, 2018) and project applications (e.g., García de Soto et al., 2018; Sawhney, Riley and Irizarry, 2020) to placing a firm focus on organisations and their hopeful transition between existing and emerging institutional practices and requirements. In applying this perspective, the paper provides a critical explanation and offers directions for future studies to complement the burgeoning literature on the transformation of the construction industry from an institutional perspective

The next section details the government-led construction industry transformation agenda in the UK, with emphasis on its technocentric nature and goal to establish aa new institutional logic. Next, we examine how these initiatives are creating new demands and placing pressures on firms operating in the industry from the perspective of a GCF. This is followed by a description of the theoretical concepts of institutional logics, change, complexity and strategic responses and how they are operationalised in our conceptual discussion. Next, we discuss how GCFs, at the nexus of change, will be faced with conflicting demands, bringing forward 
the need for strategic responses. We consequently follow this discourse to highlight key questions that arise through the lens of institutional theory and explain their relevance for the industry transformation agenda. In the conclusions we highlight implications of the proposed research avenues for industry transformation policy and practice, focusing on considerations that construction firms need to contemplate if the face of impending changes in the field of public sector procurement.

\subsection{THE CONSTRUCTION INDUSTRY TRANSFORMATION AGENDA IN THE UK AND THE GENERAL CONTRACTING FIRM}

\subsection{The Construction Industry Transformation Agenda}

The UK construction sector has historically been strongly shaped by Government policies (Winch, 2000, 2001, 2003). Through successive efforts, the construction industry has, for nearly three decades, been spurred on to transform, from a more management-focused change agenda to one that is mainly technocentric - that views digital and manufacturing technologies, among a host of others, hold the keys to an improved industry (Cabinet Office, 2011; IPA, 2016, 2019; HM Government, 2018, 2020). Industry reports emphasizing the need for change, including Egan (1998), Latham (1994), Wolstenholme (2009), Farmer (2016) and Hackitt (2018), collectively highlight several grand challenges which digitisation, manufacturing-led approaches and attendant ecosystems can help address. Collectively, the grand challenges for the construction sector include: low productivity; shortage of talent and skilled workforce; lack of standardisation; low cooperation; low levels of R\&D; adversarial procurement; poor knowledge transfer; and a reluctance to embrace technological 
innovations.

To tackle these challenges, government-led reforms to improve the UK construction industry, partially influenced by recommendations from industry reports, have increasingly become more technology-centred, incorporating a mix of coercive and voluntary measures to achieve set policy targets (Dainty et al., 2017). The 2016 mandate for building information modelling (BIM) use on all public sector projects is an example of the former (IPA, 2016), alongside the requirement from Homes England for 25\% of all affordable housing to be built using offsite manufacturing (OSM) under its £11.5bn Affordable Homes Programme (Homes England, 2020). The government's presumption in favour of the use of OSM for projects by five key ministries and departments links with the latter (IPA, 2019). The Government outlines in the latest Industrial Strategy (IS), 'Construction Sector Deal', its partnership with industry to promote the use of digital technologies and manufacturing approaches in achieving the following: reducing construction and whole lifecycle costs by $33 \%, 50 \%$ faster delivery of construction projects and 50\% cut in greenhouse gas emissions by 2030 (HM Government, 2018). In line with the preceding, The Construction Playbook outlines the Government will use public sector procurement to achieve the transformational change envisaged for the construction industry. Indeed, the target is to use the new procurement directions outlined to "standardise designs, components and interfaces as much as is possible; drive innovation and modern methods of construction, through standardisation and aggregation of demand" (HM Government, 2020, p.2). Table 1 below summarises evidence from government policies and reports that highlight the focus on industry transformation through the promotion of digital technologies, manufacturing approaches, platforms and other industry 4.0-enabling technologies. 
Table 1: Evidence of Government focus areas on construction industry transformation

[Insert Table 1 here] 
From Table 1 the incremental focus of the UK Government to promote the adoption of more and more innovative technologies is evident. Majority of industry transformation initiatives have, over time, become underpinned by elements of 'digitalisation', 'manufacturing' and 'platforms'. Other industry reports (e.g., Farmer, 2016; NHBC, 2018; De'Ath and Farmer, 2020) echo a similar point - the need for transformation underpinned by technologies. The goals remain fairly similar, with emphasis on innovation, change, or transformation - all focused on achieving significant productivity improvements across the industry. Proposed benefits to be realised from such an eclectic mix of technologies include improved productivity; improved cost performance, safer work environment; improved sustainability performance, increased collaboration and the realisation of new value from improved project delivery processes (Cabinet Office, 2011; HM Government, 2013, 2018).

As a significant industry actor and client, the Government seeks to gain from these benefits and so is clearly repositioning itself, through The Construction Playbook (Government, 2020), and using the power of public sector procurement to demand for the use of BIM and other digital technologies, platforms and standardised components, and the creation of digital twins for built assets (HM Government, 2020). Although this is not new (see: Latham, 1994; Egan, 1998), the attention to digitalisation, manufacturing and platformisation is now strongly represented. Across a number of initiatives, the Government is spearheading the deployment of a raft of these innovative technologies as a client, funder or facilitator. Oti-Sarpong and Burgess, (2020, p.7) highlight that part of efforts to promote a widespread adoption of OSM includes "the commissioning of a $£ 253 \mathrm{~m} 1,680$ capacity resettlement prison by the Ministry of Justice; the Department for Business Innovation and Skills giving a $£ 22.1 \mathrm{~m}$ grant to Laing O'Rourke for the development of offsite manufacturing 
solutions; and a £38m joint housing scheme between Homes England, local authorities and private developers across the country". With the implementation of the BIM mandate serving as a backbone innovation, there is an increasing push for the use of standardised construction components, platforms and the creation of digital twins (CLC, 2020; IPA, 2020). The aim of the Digital Built Britain programme is to create a national register of all built assets in digital form that can be used for infrastructure-related planning and decision-making for the development of society (CDBB, 2020). Additionally, the Government has commissioned, under the $\mathrm{CDBB}$, the development of a "platform construction system consisting of a standardised kit of parts" to be used for the delivery of social infrastructure buildings (Bryden Wood \& CIH, 2018). As part of a client-led demand push for the use of manufacturing-based approaches for project delivery, it will initially be adopted by five government departments (Education, Health and Social Care, and Transport) and ministries (Justice and Defence) under a 'presumption on favour of offsite construction (IPA, 2019). Based on goals outlined in policy documents, the implementation of these initiatives is geared towards the realisation of significant step changes in how the construction industry works, which will cumulatively lead to the attaining a transformed construction industry in the UK (HM Government, 2018, 2020).

From the extracts in Table 1, an ultimate goal of the government-led initiatives being implemented under the transformation agenda is to reconfigure existing/long-standing preferred arrangements (i.e., norms, values, logics, practices) in the construction industry. The reconfiguration will impact the processes of planning, design, procurement, construction and management of built assets (cf. Oti-Sarpong \& Burgess, 2020). For example, according to the Centre for Digital Built Britain (CDBB) Strategic Plan, the Government wants "to make fully computerized construction the norm" (HM Government, 2015, p.5). Indeed, the policy 
documents provide evidence that the Government is aware of the structural reconfigurations that accompany the transformation agenda. To facilitate the realisation of the DBB strategy, for instance, the Government notes how "changes to existing commercial models will be required to deliver the opportunities for performance improvement identified" (HM Government, 2015, p.23). Related to the platform approach initiative, it is made evident how "the scale of the challenge of implementing this strategy is not underestimated," and how "it would require significant change within a large and well-established market, an evolution of procurement and assurance practices as well as some new performance benchmarks and different types of jobs in the labour force" (IPA, 2019, p.8).

Based on the preceding we can draw attention to how ongoing government-led industry transformation initiatives hold implications for existing institutional arrangements related to (inter)-organisational practices in design, procurement, construction and management in the construction industry (cf. Winch, 2003). From the policy documents we can gather how the Government has re-echoed its intentions to utilise its 'procurement power' over the years, with an arguably refreshed stance in The Construction Playbook (HM Government, 2020). Accompanying this are calls for main and subcontractors, alongside other construction supply chain firms, to 'meet the challenge' (HM Government, 2013), respond to what the Government 'expects and will contract for' and apply the principles and policies outlined (ibid, 2020). Put differently, firms in the construction supply chain are in a position where they are to embrace the impending / ongoing institutional reconfigurations that are part of the transformation agenda. It follows from the foregoing that reconfigurations are often characterised with a transitional phase of complexity arising from the existence of different and competing arrangements or 'logics'. Understanding the institutional implications of the transformation agenda, as well as how firms might navigate issues of complexity in order to 
remain active in the field of public sector construction, remains unclear in existing literature. Winch and Maytorena-Sanchez (2020) however, provide evidence for how a large 'institutional project' was launched by the UK Government in response to institutional complexities that emerged as a result of contradictory modes of competition and collaboration in the field of defence acquisitions. From this project, actors in the field gained shared understandings of government and client demands, helping them navigate the procurementfocused complexity and spur them onto actions in response to the requirements. In exploring how project-based firms respond to the UK Government's narratives of innovation, Sergeeva and Winch (2020) found that project-based firms, including large general contractors, already identify the need for more strategically informed responses of their firms to demands to innovate mainly in order to keep winning projects. The challenge such firms face, however, includes combining developing clear guiding strategies, prioritising their responses to these demands and maintaining their operational focus - a product of the pressures the transformation agenda brings.

To realise the espoused step changes as part of construction industry transformation in the UK, Oti-Sarpong and Burgess (2020, p.4) highlight that it requires "multi-layered adjustments to the established and preferred ways of delivering construction projects", to be actioned by firms in the construction supply chain. From the evidence provided in Table 1, the government identifies itself as a key actor to trigger innovation (cf. Sergeeva and Winch, 2020; Ernstsen et al., 2021), and responsibility for 'on-the-ground' actions through the delivery of projects and manufacture of products for built assets is strongly placed on construction firms in the supply chain network. With the Government interested in using public sector procurement to trigger transformation, construction firms involved in the delivery of public sector projects are expected to 'work more efficiently', develop capabilities 
to work collaboratively with others, effectively respond to the demands to innovate. Despite the assumption that such 'top-down' pressures will be met with compliance often not being the case especially in construction (cf. Dainty et al., 2017; Green, 2019) studies tend to take that as a given. An alternative view of the pressures from the transformation agenda on construction firms, how they might respond, and potential implications has attracted scant interest in policy and academic discussions. These are the issues we highlight in this paper, from an institutional theory perspective and with emphasis on the general contracting firm as the actor at the nexus of the ongoing transformation agenda in the UK.

\subsection{At the nexus of change: The perspective of the General Contracting Firm}

In the UK, construction accounts for about $6 \%$ of economic output and provides employment for 2.3 million people - which is $7.1 \%$ of the total work force in the country (Green, 2014). GCFs contribute significantly to the industry's economic output, accounting for construction work (residential and commercial buildings, roads, airports, sewerage, tunnels, rails, etc.) up to the value of $\sim £ 170 \mathrm{bn}$ (as at the end of the third quarter in 2018) and employing roughly 1.5 million people in Britain alone. This represents $65 \%$ of total employment the entire industry provides nationally, not including other forms of employment that are associated to the activities of GCFs in places where they undertake projects, contributing to the economic productivity of those localities. Accounting for these employment numbers is 80,741 GCFs in main (undertaking buildings and civil works) and 325,736 in allied (undertaking specialized work including demolition, site preparations, electrical installations, plumbing and HVAC, roofing, glazing, painting, scaffolding, etc.) trades respectively (ONS, 2018). The contributions of GCFs from the preceding reveal how their functions are critical for the construction industry to remain a relevant contributor to the 
UK's economic output.

The preceding underscore the importance of GCFs as indispensable actors in the construction industry. Indeed, they comprise the central 'integrating' entities in project delivery, constituting an important group of firms in the construction industry (Farmer, 2016). At the centre of the productive activities, they are responsible for, among others, translating digital computer-aided design, models or manually produced designs into actual products through a combination of resources and deploying management capabilities for both public and private project clients (cf. Dainty et al., 2017). A strong resource dependency relationship therefore exists between contractors and the clients for whom they work and so the former tends to be more responsive to demands from the latter.

By virtue of their work, they are always under multiple sources of pressures to which they must respond through a mobilisation of organisational capabilities, technologies and human resources. Figure 1 summarises conceptualised layers of complexity that face GCFs. In performing their critical functions in the construction industry, GCFs sit at the nexus of the multidirectional pressures from sources including policy, professional practice requirements, regulations and clients. To meet project needs of clients, main (who are typically large firms) contractors form a network with other specialist (sub) contractors, consultants, suppliers and manufacturers and coordinate this network within established institutional frameworks (Rasmussen et al., 2017). Additionally, in undertaking projects, contractors manage requirements and pressures from various industry actors including regulatory and professional bodies (Vermeulen et al., 2007). This includes performing project-related functions according to established safety regulations, implementing measures to protect workers' health, paying fair wages, observing fire regulations, and adhering to guidelines from associations of 
professionals like engineers, architects and project managers engaged. An additional source of pressure involves undertaking their operations and (re)configuring internal structures within the confines of established practices that are deemed acceptable in regulative, normative and cognitive frameworks. Doing so is essential for their peer and social approval, legitimacy and survival (Green, 2013; Farmer, 2016). These pressures, as discussed in the previous section, are already changing practices with increasing demands to deliver public sector projects with a preference for the use of manufacturing, digitalisation, platforms (see: IPA, 2016; HM Government, 2020). The increasing pressures will invariably be attendant with new pressures to which contractors will have to respond as it is critical for their survival in the field of operation (see Figure 1).

\section{[Insert Figure 1 Here]}

\section{Figure 1: Conceptual summary of layers of complexity for General Contracting Firms}

In the seemingly unending rhetoric around the 'transformative power' of digitalisation, manufacturing and other modern technologies, there is the implied assumption that the transition to new ways of working will be client-led and that construction firms will simply comply (cf. Farmer, 2016; Gottlieb et al., 2020). This viewpoint has however been shown not to be the case all the time, particularly considering that firms are not simply passive conformists to demands, and they prioritise their self-interests (Oliver, 1991; Pache and Santos, 2010; Micelotta et al., 2017). From a resource-dependence viewpoint, contractors are likely to be compliant and simply comply with new demands from the clients, regulators and other actors in line with the transformation agenda. However, given the fragmented and moderately centralised nature of the industry, its high uncertainty, multiplicity of actors 
imposing different demands, and organisational agency and self-preservation interests, full compliance to these new demands is not a given (Vermeulen et al., 2007; Pache and Santos, 2010).

Despite their centrality in the implementation of techniques and technologies that would lead to 'real' transformation, there is barely any clear attempt in the extant literature, to contribute an understanding of how GCFs might respond to the pressures arising transformation agenda in the construction industry. Particularly scare from the discourse are views exploring critically how the agenda to change the construction industry on the basis of a widespread use of digital technologies, manufacturing approaches and platforms, presents issues of institutional complexity that needs closer examination if the desired policy outcomes might be realised. Given GCFs' significant contributions to the sector's activities and economic output as a whole, these constituents deserve critical attention to better understand how transformation agenda underpinned by new technological paradigms might impact them and consequently, the implications that would hold for the realisation of a 'revolutionised' sector as outlined in policy and reform documents. In the sections that follow, we discuss concepts of institutional logics, institutional change (Micelotta et al., 2017), institutional complexity and strategic responses (Oliver, 1991; Pache and Santos, 2010) and how they are employed to critically analyse implications of the transformation agenda on GCFs, and consequently identify key questions for future enquiries.

\subsection{THEORETICAL LENS}

3.1 Institutional logics, arrangements, complexity and strategic responses 
Institutional theory provides a framework for exploring "the processes by which structures, including schemas, rules, norms, and routines, become established as authoritative guidelines for social behaviour" (Scott, 2004, p. 460). A collection of systems of meaning and patterns of behaviour that control and support actions in a field captures what an institution is (Meyer and Rowan, 1977; DiMaggio and Powell, 1983); and the "sociocultural constructions that prescribe appropriate organisational behaviours and that shape and enforce patterns of interest and privilege" are the arrangements that characterise it (Micelotta et al., 2017, p.1886). Institutional arrangements are therefore the 'operating systems' that capture existing configurations in a context, shaping and being shaped by institutional actors in a field. Here, we borrow from DiMaggio and Powell (1983) and Barley (2010) to define a field as a recognised area of institutional life comprising actors (e.g., supplier firms, regulatory agencies, clients and consumers) interacting within defined rules and through established norms in a network towards a purpose. Public sector project delivery can thus be seen as a field - in the wider institutional setting of construction - comprising actors including general contracting firms, components manufacturers, clients (e.g., government bodies) and regulatory agencies engaged in a network that is guided by established institutional arrangements for the purposes of providing infrastructure (e.g., roads, schools, hospitals and housing) for society.

According to Micelotta et al. (2017), the emergence of the concept of institutional arrangements has given more clarity to research using institutional theory to better unpack the sources of institutional changes, how they occur, implications of changes, and consequent impacts on actors. At the heart of arrangements, they posit, are institutional logics, which Thornton et al. (2013, p.2) define, as "socially constructed historical patterns of cultural symbols and material practices, including assumptions, values and beliefs". Institutional 
logics thus comprise shared rules, routines, values, beliefs, practices and norms that are established among actors that define an existing institutional arrangement. Based on their synthesis of literature on institutional theory, Micelotta et al. (2017) underscore that the concept of logics allows for the questioning and empirical explorations of how existing structures might undergo reconfiguration as a result of institutional change, as well as implications for organisational responses, micro practices within and between firms, and the identities of professional actors. The institutional logics perspective has thus been described as an analytical framework (Thornton et al., 2013) or a meta-theory (Thornton and Ocasio, 2008), useful for generating understandings about individual and firm behaviours in an institutional context that is undergoing changes. Thus, it is based on the concept of institutional logics that institutional change and complexity can be explored with clarity, given their linkage.

Institutional change involves the replacement of one dominant logic by another. It is a process through which established values, beliefs, practices and norms are reconfigured or transformed from one form to another (Greenwood et al., 2011; Thornton et al., 2013; Ocasio, Laamanen and Vaara, 2018). Examples include widescale transformation attempts, such as promoting the adoption of big data analytics powered by artificial intelligence for sustainable manufacturing in South Africa (Bag et al., 2021), and the Dutch government's attempts to reconfigure the concrete manufacturing sector by making it more sensitive to issues of environmental sustainability through the use of alternative materials (Vermeulen et al., 2007). Given that institutional change is typically gradual and not episodic (Micelotta et al., 2017), there is always a transitional phase. It is in the transition period that firms have to grapple with the pressures of complexity and enact responses they deem suitable based on selfinterests and the need to survive in their field of operation. Actors operating in a field with 
more than one logic face institutional complexity at a given time (Greenwood et al., 2011). The logics may be contradictory, paradoxical, competing or conflicting. Regardless of the kind of complexity existing, firms grapple with the challenges of operating in such a field and can respond in a number of ways (Oliver, 1991), including the formation of a hybrid entity (Pache and Santos, 2010), creatively combining logics (Dalpiaz, Rindova and Ravasi, 2016), and/or employing symbolism (Meyer and Höllerer, 2016). In sum, multiple institutional logics do present firms operating in an institutional field a challenge of complexity to which they must respond in one way or another.

In addition to the problem of institutional complexity, the existence of multiple institutional logics as a result of institutional change impinges pressures on institutional actors (Oliver, 1991; Pache and Santos, 2010). Put differently, multiple logics create a problem of complexity, which bears pressures on firms operating in a field. In the institutional theory literature, Oliver (1991) posits a theoretical framework that suggests five strategic responses that are likely to be enacted by firms faced with pressures emanating from complexity. Underpinning the theoretical framework is the understanding that firms are not passive conformists to demands derived from institutional logics, and that they will consider their self-interests and resource dependence relationships with referents such as clients/funders, regulators and competitors in enacting different (strategic) responses to pressures when confronted. The nature of responses firms may enact when faced with pressures arising from complexity can be predicted through an understanding of the: reasons for the demands underpinning them (cause), nature of the requirements (content), institutional constituents behind them (referents), mode of enforcement (control) and nature of the institutional environment (context). Depending on how these predictors interact in an institutional setting, Oliver (1991) argues that firms are likely to find five strategic responses, namely 
acquiescence, compromise, avoidance, defiance and manipulation appealing. The choice firms would consequently make from these responses gives an indication of the extent to which institutional configurations (e.g., resource dependence on clients) presses them to simply comply by acquiescing, or give room for them to explore varying degrees of resistance in the form of compromise, avoidance, defiance or full manipulation of the sources and nature of the pressures. Pache and Santos (2010) build on Oliver's (1991) predictive framework by indicating how the ability and/or willingness of a firm to enact any response is also influenced by internal organisational dynamics, such as professional identity that is either bolstered or challenged by implications of any of the responses to pressures being faced. The selection and enactment of responses to institutional pressures arising from complexity is therefore simply not a product of resource dependence and self-interest considerations alone; internal firm dynamics are part.

Three key issues can be highlighted from the preceding discussion. First, attempts to alter a set of established logics (norms, practices) in order to change institutional arrangements creates a problem of complexity which creates pressures that actors have to contend with and respond to in order to keep operating in a field. Second, a firm's willingness and ability to choose a response along a compliance-resistance spectrum and enact it in response is linked to the nature of resource-dependent relationships they share with other institutional actors (e.g., clients) and internal organisational dynamics. Third, attempts to implement large-scale changes to established practices in any sector or industry hold far reaching implications for institutions as well as their actors - issues that can be given critical attention through institutional theory. We carry forward these insights in our critical discussion of the ongoing construction industry transformation agenda in the UK in order to highlight directions for future research by posing critical questions. In doing so, a key point of 
departure is that the UK Government's policies and consequent demands for construction firms to adopt and use digital, manufacturing and other technologies are clear attempts to reconfigure existing institutional logics and consequently arrangements of the construction industry.

In the neighbouring areas of manufacturing and construction, relevant studies have drawn on institutional theory to contribute understandings about large-scale change agenda (e.g., Vermeulen et al., 2007; Reischauer, 2018), with emphasis on institutional pressures for change and their sources (e.g., Jacobsson et al., 2017; Bag et al., 2021), how transformation is triggered (e.g., Hetemi et al., 2020), and how firms respond to complexity and pressures impinged (e.g., Gottlieb et al., 2020). Bag et al. (2021), Reischauer (2018), Vermeulen et al. (2007) and Jacobsson et al. (2017) in their study of manufacturing and construction industries, underscore how technology-focused government policies can critically shape institutional configurations and how actors (firms) operate. Through a critical evaluation of the German 'High Tech Strategie', Reischauer, (2018) underscores how policy serves as a tool to institutionalise innovative practices as part of an industry transformation agenda in manufacturing. In Hetemi et al., (2020), they employ the institutional logics concept in order to explore how institutional configurations impact how project-based firms (PBFs) undertake temporary organisations (e.g., projects). Their findings show that institutional field shifts in logics are accompanied with multiple institutional demands which impact decisions how managers in PBFs implement legitimising responses. Winch and Maytorena-Sanchez (2020) and Sergeeva and Winch (2020) also emphasize how government policy narratives drive innovation responses among PBFs in the construction industry. Gottlieb et al. (2020) identified that hybrid organisations are used in response to changing institutional logics, and also highlight how multiple institutional demands are addressed through the articulation of 
new logics, disassociation from existing practices, roles redefinition and collaborative practices. To this end, they show how institutional logics are combined in order to satisfy multiple and potentially divergent institutional demands, highlight the nature of the logics (dominance and consequences) and describe the stability of the hybrid organisation. Their main theoretical contribution is their proposition of a dynamic understanding of how multiple (conflicting) logics coexist and how hybrids emerge and evolve over time through processes of blending and segregating the logics in the context of the institutional complexity within which organisations operate.

Despite the insights gained from these studies, completely missing from existing literature is an attempt to discuss how any large-scale change agenda presents an institutional quandary for firms, following which questions can be raised for future research in order to generate new insights about construction industry transformation attempts through the lens of institutional theory. It is this contribution that we offer in this paper. In the discussions that follow, we take forward insights from the institutional theory concepts presented in this section to advance arguments that highlight critical questions for future research about construction industry transformation.

\subsection{DISCUSSION: TOWARDS A RESEARCH AGENDA}

\subsection{Construction industry transformation agenda: Changes to institutional logics and arrangements}

From the discussion of the UK's ongoing construction industry transformation agenda, we highlighted how the implementation of policy was introducing series of changes. 
Gleaning from the policy documents reviewed, key existing logics that are going to be affected can be identified across the processes of planning, design, procurement, construction and management of built assets. The Construction Playbook clearly states how the Government is going to "procure construction projects based on product platforms comprising of standardised and interoperable components and assemblies, the requirements for which will be part of a digital component catalogue" (HM Government, 2013, p.20). The change in the Government's commercial model is a clear effort to reconfigure procurement practices across the supply chain, with implications for early involvement, stronger collaboration, early-stage detailed design finalisation. Through a study of 15 years of government and industry initiatives including four mega projects related to London's digital ecosystem, Whyte (2019) provides evidence for how digitalisation and digital information are transforming project delivery models. New digitally enabled project delivery models are becoming increasingly enabled through the deployment of digital technologies, with implication for procurement routes, supply chain relationships with owners, operators and project end-users. The digitalisation of information is also reconfiguring workflows from being documents-based to digital workflows. Tee, Davies and Whyte (2019) also highlight, based on a study of London's Terminal 5 Project, that using modular designs for projects bring forward the need for firms to be able to coordinate and collaborate better - something that existing models of operating are not necessarily designed to accommodate. The platform approach for project delivery, Oti-Sarpong and Burgess (2020) assert, is also shaping design, construction practices and professional practices in the architectural, engineering and construction industry. They provide that the P-DfMA's principles of 'design for manufacture', 'platform centredness' and being 'open for manufacture, use and 
procurement' are directly changing the practices of design for on-site construction which prevails in the existing preferred practices of the industry - to component-based project delivery, changing skills requirements in the industry, reconfiguring manufacturing platforms and production systems to suit the fabrication of standardised components and presenting a significant shift from bespoke designs for projects towards undertaking designs within new parameters for interoperability. From these examples, we can gather that the government led industry transformation agenda is already changing existing logics for design and construction processes in the industry and impacting how the majority of GCFs, who are typically project-based firms, will organise and undertake projects. How these changes might occur, their implications for firms in the field of public sector project delivery and the wider institutional setting is brought into focus here.

Through the lens of institutional theory, we can begin to explore the nature of change the construction industry is undergoing as part of the reconfiguration of logics and arrangements. According to Micelotta et al. (2017), institutional change could be transformational or developmental. It is transformational when shared understandings defining what is accepted and valued in the field, are upturned or altered significantly. Transformational change can occur through replacement, blending, or segregation of institutional logics. Change is developmental when adjustments are relatively narrow, and involves a stretching rather than discarding of institutionalized arrangements. such change can occur through the contraction, assimilation, or elaboration of institutional logics. Whilst the industry change espoused in policy documents are usually labelled as 'transformational', it is difficult to find evidence that a significant overhaul to the existing 
preferred ways of working has been achieved. Oti-Sarpong and Burgess $(2020$, p.480) in a multi-level analysis of the UK's construction transformation agenda conclude that despite pressures from government, "overarching structures, rules of practice and established norms among actors (e.g., clients, contractors, consultants, planning authorities, technology vendors) that presently govern the construction industry are deeply embedded in configurations that are not oriented to allow a widespread adoption of offsite manufacturing". A recent survey by the NBS (2020) also shows that over $47 \%$ of construction firms in the UK, on average, are never going to, or do not know if they will use technologies like design for offsite construction, 3D printing, analytics and big data, digital twins, sensors and machine-to-machine communication and $\mathrm{AI} / \mathrm{machine}$ learning in the future. This is in spite of expressed awareness by nearly $48 \%$ of respondents that demands to use BIM and such technologies for projects will be increasing in the future. Project-based firms are, however, reported to have started recognising the changing logics and the need to identify a suitable response strategy (Sergeeva and Winch, 2020) and others also re-enacting existing practices that are in opposition what new logics require (Zomer et al., 2020). According to a report by the House of Lords (2018), widespread change is challenged because procurement routes for the majority of projects continue to promote adversarial relations, and that supplier networks are continued to be developed based on broken-down work packages where the lowest bid wins and processes of construction remain heavily labour-intensive and insitu. These are contradictory to the new logics that the industry transformation agenda are designed to establish. The mixed bag of observations regarding policy-led change is unsurprising, considering the persistent difficulties past policies are reported to have faced in attempts to 'overhaul' or 'restart' the industry (Green, 2019, 2021). The mixed 
nature of developments makes it unclear the nature of change that the policy-backed industry transformation agenda has been able to achieve, if any at all. On the basis of the preceding, we identify the following research questions for future inquiry:

- Research Agenda 1: What kinds of changes have occurred in the construction industry as a result of the industry transformation agenda?

- Research Question 1b: What logics have been impacted significantly or narrowly?

- Research Question 2a: How are any changes in established logics impacting existing structures of the construction industry, the field of public sector project delivery?

- Research Question 2b: Are changes arising from the policy-backed initiatives changing logics and arrangements, or leading the creation of a new institutional field as part of industry transformation?

\begin{abstract}
Although studies discussing change in the construction industry often cite ongoing transformation agenda in the areas of digitalisation, platformisation and manufacturing, for instance, as motivations, there is rarely any effort to critically scrutinize its implications for established structures, including schemas, rules, norms, and routines (cf. Scott, 2004). By bringing forward how the industry transformation agenda triggers changes to institutional logics and arrangements, we draw attention to the need for a deliberate interrogation of what has hitherto been ignored, or implied in existing literature
\end{abstract}


at best. There is scarcely any clearly articulated understanding of the nature of such changes among construction firms in the industry - whether they are transformational, or developmental, and how they relate with prevailing structures governing the industry and how they shape organisational practices. Through longitudinal studies, we might gain a better understanding of the how institutional logics in construction are (not) changing as a result of industry transformation agenda and its attendant pressures. It is anticipated that explorations inspired by these questions, and situated in the 'loosely coupled' construction industry (cf. Winch, 1998; Dubois and Gadde, 2002), hold the potential to inform how Government policies driving large scale systemic innovation agenda could be designed in ways that take into consideration the intricacies of coexisting logics in such a setting (cf. Zomer et al., 2020). They would also complement literature on large-scale innovation agenda with insights from largely project-based firms through the lens of institutional theory (cf. Jacobsson et al., 2017)

\subsection{The transformation agenda and GCFs: Institutional complexity, pressures and potential responses}

Taking forward the understanding that institutional change is gradual, the coexistence of multiple (conflicting) logics cannot be ignored (Micelotta et al., 2017). The challenge of institutional complexity is thus embedded in any agenda to change existing norms, and routines from one form into another, and firms operating in a field have to face these pressures. For instance, under the current UK BIM framework, the ISO 19560 (4th Edition), for instance, it is advised for GCFs to meet clients' demands for organisational information (OIR), asset information (AIR) and exchange information (EIR) requirements by providing a BIM execution plan (BEP), and project information (PIM) 
and asset information (AIM) models (HM Government, 2015). Owing to the resourcedependency relationships GCFs share with project clients, their demands are more pressing and a source of pressure that would need addressing as the industry logics of design, construction and asset management undergo transitions. Whilst the presumption in favour for OSM is yet to be backed by a legal mandate, the Government's renewed position in The Construction Playbook is a clear example of how procurement is being used to exert pressures of change. As studies including Whyte (2019), Tee et al., (2019), Zomer et al., (2020) make clear, delivering projects based on logics prescribed by digital technologies and manufacturing led approaches differ from project delivery that is based on existing 'conventional' techniques. GCFs, who mobilise technologies, human resources and (inter/intra) organisational capabilities to execute projects therefore need to tackle the complexities the existence of these multiple logics present them (cf. Micelotta et al., 2017). It follows from the examples given here and in the previous sections (see Section 2.1 and Table 1) that firms operating in the field of public sector project delivery in particular, are faced with the problems of institutional complexity and attendant pressures under the UK's construction industry transformation agenda.

The key institutional actors we focus the attention of our discussion on are general contracting firms (GCFs). In section 2 we established how the implementation of policyled transformation agenda in the UK bears direct pressures on these project-based firms who are primarily involved in implementing techniques and technologies that can respond to the Government's innovation narratives (Sergeeva and Winch, 2020). By virtue of their function, GCFs find themselves at the nexus of change, having to respond to various demands from multiple institutional referents including clients and regulators 
who often have conflicting demands. In addition, they operate in a highly uncertain industry that is characterised by high degree of fragmentation and moderate centralisation. These field characteristics exacerbate the problems of institutional complexity that arise from the existence of multiple (conflicting) logics. The survival of GCFs in a future where the new logics - driven by digitalisation, platformisation and manufacturing-led construction, for instance - are dominant rests on their willingness and/or ability to enact strategic responses they deem appropriate.

When faced with complexities and pressures, firms operating in an institutional field take steps to select and enact responses by giving consideration to their context and their own survival (Oliver, 1991; Pache and Santos, 2010, 2013). The predictive framework Oliver (1991) offers a useful lens through which the state of the UK's construction industry transformation agenda can be understood in order to serve as the basis for an investigation into the kinds of strategic responses that might be enacted by GCFs. In this discussing the framework earlier, we indicated that the nature of responses firms may enact when faced with pressures arising from complexity can be predicted through an understanding of the: reasons for the demands underpinning them (cause), nature of the requirements (content), institutional constituents behind them (referents), mode of enforcement (control) and nature of the institutional environment (context). As a basis for outlining questions for future research, Table 2 presents a summary of key characteristics of the institutional context GCFs operate in and the transformation agenda currently underway. 
Table 2: Summary of defining features of the UK construction industry transformation agenda through Oliver's (1991) framework

\begin{tabular}{|c|c|}
\hline Feature & Defining characteristics \\
\hline Cause & $\begin{array}{l}\text { Creation of an efficient and productive sector to reduce project delivery } \\
\text { and operating costs, produce energy efficient assets and create an } \\
\text { interconnected built environment. }\end{array}$ \\
\hline Content & $\begin{array}{l}\text { Adoption of different digital, manufacturing and platform technologies } \\
\text { linked to other cyber-physical systems technologies to change industry } \\
\text { practices (e.g., procurement, (inter) organisational practices for project } \\
\text { design, construction and asset management). }\end{array}$ \\
\hline Referents & $\begin{array}{l}\text { Multiple constituents - Government, public sector clients and arms- } \\
\text { length bodies, private clients, public procurement entities, several } \\
\text { regulators - making varied demands which GCFs need to respond. } \\
\text { Strong resource dependence mainly between GCFs and clients. }\end{array}$ \\
\hline Control & $\begin{array}{l}\text { Mixed control measures: coercive/obligatory (mandates; procurement } \\
\text { requirements) and voluntary diffusion measures. Moderate coercive } \\
\text { measures (BIM mandate and OSM presumption in favour for OSM) } \\
\text { currently in use. High voluntary diffusion mechanism (bottom-up } \\
\text { initiatives) encouraged. }\end{array}$ \\
\hline Context & $\begin{array}{l}\text { Characterised by very high uncertainty and very low } \\
\text { interconnectedness because the industry is fragmented }\end{array}$ \\
\hline
\end{tabular}


A firm's enactment of any of the five strategic responses Oliver (1991) posits is a result of interactions between the characterising features of the source of complexity and pressures, and the considerations about organisational self-interests, resource dependence relationships, and internal organisational dynamics (Pache and Santos, 2010, 2013). According to Oliver (1991), a firm's strategic response to institutional complexity and pressures is linked to the extent which institutional configurations (e.g., resource dependence relationship with clients) presses firms to comply by acquiescing, or allows them to explore varying degrees of resistance in the form of compromise, avoidance, defiance or full manipulation of the sources and nature of the pressures. Pache and Santos (2010, 2013) expand on Oliver (1991) framework by highlighting how the ability and/or willingness of a firm to enact any response is also influenced by internal organisational dynamics, including how professional representation in a firm is either bolstered or challenged by implications of any of the responses to pressures being faced.

The theoretical insights from Oliver (1991) and Pache and Santos $(2010,2013)$ about institutional logics and firm responses have been employed in relevant constructionfocused literature (e.g., Gottlieb et al., 2020; Hetemi et al., 2020; Frederiksen, Gottlieb and Leiringer, 2021). Whilst some responses from firms towards institutional complexity might include the formation of a hybrid organisation that is usually indeterminate, Raynard and Greenwood (2014) identifies that projects comprise another organisational response. The use of projects is found to be particularly useful in fields characterised by volatility in complexity, where "there is incompatibility between institutional logics, there is an unsettled prioritization between them, and it is not possible to separate organizationally the "jurisdictions" of the incompatible logics" (ibid, p.369). Echoing 
Raynard and Greenwood (2014), Winch and Maytorena-Sanchez (2020, p.369) submit that whilst several project-based firms (PBFs) "face institutional complexity, it is not clear that hybridization is always the appropriate organizational response". What alternatives then, are GCFs - largely PBFs by nature - enacting in response to the institutional complexity they are being confronted with under the UK's ongoing industry transformation agenda? Hetemi et al., (2020), show that the existence of multiple institutional logics impact how construction firms undertake projects, with direct impacts on how managers in implement responses to cement their firms' legitimacy in the face of change and complexity. Gottlieb et al. (2020) identified that hybrid organisations are used as trading zones by project-based firms in response to changing institutional logics. The use of such an indeterminate solution by firms is deemed feasible, especially when the coexistence of multiple (conflicting) logics and their evolution over time are taken into consideration. Frederiksen et al. (2021) also show, from studying a major Danish construction programme, how the main firm adopts a compartmentalised structural approach in tackling conflicting logics that are completely distinct. This governance mechanism was deemed a useful strategic response by the leading PBF coordinating the large programme in dealing with three distinct institutional logics. A number of observations are evident from the preceding. First, projects can be organised and executed as a direct response to institutional complexity, without specific impacts on the permanent firm. However, doing so in the construction industry, raises concerns about organisational ambidexterity and capabilities. For general contracting firms to effectively undertake projects that meet specific technological requirements (e.g., an increased use of digital manufacturing) from clients within the regulatory framework, whilst continuing to operate in the field of construction where such requirements are not prioritised, they must 
have the internal capabilities that will afford them the ability to respond to such demands. Also, with the complexities of logics usually examined being project-based, there is scarcely any focus on how PBFs respond to complexities arising from a large-scale reform like the ongoing transformation of the UK construction industry. Another observation from studies that have examined responses of project-based firms when faced with complexity is the attention on the deployment of strategic responses using temporal organisation (i.e., projects), with little emphasis on the permanent PBF as institutional actors, and how those responses hold implications for their fields of operation.

Drawing on the discussions that have preceded this section, the key characteristics about government-led industry transformation agenda summarised in Table 2, and Oliver (1991) framework for predicting potential strategic responses by firms when faced by institutional complexity, a number of research questions can be identified.

- Research Question 3: What are the detailed characterising features of the industry transformation agenda and what are the degrees of impact they are exerting on GCFs?

- Research Question 4a: What is the relationship between the degrees of impact of the characterising features of the transformation agenda and the strategic responses enacted by GCFs?

- Research Question 4b: What is the relationship between different kinds of control measures in enforcing demands under the policy agenda and responses from firms operating in the field? 
- Research Question 4c: What are the modifying effects of the characteristics of the field of public sector project delivery on institutional complexity faced by GCFs?

- Research Question 5: How are institutional referents interpreting and implementing the policy directives related to the transformation agenda?

- Research Question 5b: How are their actions contributing to institutional complexity and changes in institutional arrangements?

- Research Question 6a: What range of responses are practically being implemented by GCFs?

- Research Question 6b: What internal factors in GCFs (e.g., professional affiliations) are shaping the responses that are found attractive and consequently deployed?

- Research Question 6c: How are the responses impacting existing structures in the field of public sector project delivery, and the wider construction industry?

- Research Question 7: How are the responses enacted by GCFs impacting the development of any ambidextrous capabilities in tackling institutional complexities arising from the policy driven construction industry transformation agenda?

The research questions put forward is an invitation for researchers to explore the intra and inter organisational aspects of how firms tackle issues of complexity. By exploring these questions in the context of construction industry transformation, the empirical 
answers can provide insights beyond the project-centric findings in the handful of existing studies that are not specifically situated in the transformation discourse. The understandings to be gained from these questions are critical for the formulation of policies and implementation strategies that are sensitive to potential structural implications to be felt in the construction industry and their consequent effects on the realisation of espoused goals. Practical findings to be gained from answering these questions hold significance for how GCFs can strategically face the period of change that the implementation of the transformation agenda has already triggered.

\subsection{CONCLUSIONS}

Industry reforms advocating for the widescale adoption and use of innovative technologies and approaches - often loosely associated with the introduction of industry 4.0 as a 'new paradigm' to transform construction - have garnered a lot of research, policy and industry attention. However, critical voices in ongoing discussions about industry transformation, the 'revolutionary' power of the innovations and how key actors will respond are scarce. A majority of the technocentric literature takes for granted how firms in the construction industry will respond to the demands that advanced digitalisation, manufacturing and use of platforms, for instance, will place on them. In doing so, the literature is saturated with studies that mostly advance knowledge on the development of appropriate technologies, giving limited attention to the firms who will end up investing into and implementing them in project delivery. A high degree of technology-optimism bias also underpins existing studies about the transformative power 
of construction 4.0 in the construction industry. Whilst this holds some merit, the accompanying assumptions suggest that firms in the sector will simply conform to requirements that institutional referents such as the government, clients and regulators will place on them to demand adherence. This view is misleading for policymakers as there is barely any consideration for the self-interests and agency of construction firms to make choices that may not necessarily lead to conformity.

This paper has made an attempt to tackle these key issues in policy and research related to industry transformation by advancing two key arguments. The seemingly unending rhetoric in academic literature and industry reports around the 'transformative power' of industry 4.0-related technologies for the construction sector conveniently assume that once the pressures are put on construction firms to reconfigure their internal and external structures and practices, conformity is guaranteed. This is however not the case. First, we underscored how achieving industry transformation has consequences for firms in the construction industry. From an institutional perspective, it triggers the creation of new sets of logics and arrangements that would compete with those already existing. Second, we argue this would subsequently present actors, specifically general contracting firms (GCFs), in the field a problem of complexity to which they must respond in order to survive. The responses of such firms to the complexity are not to be taken for granted since they have the agency to consider their self-interests and enact strategic responses that they would deem suitable for their survival.

By synthesizing evidence from the UK construction industry transformation agenda and critically analysing its implications for institutional logics, arrangements and complexity 
in the existing structure of the industry we outline research questions for future enquiry. The proposed research questions are positioned to inspire more critical research into these areas using institutional theory as the lens. We consider these questions to be deserving of attention if policy objectives might be realised, and deeper insights about the attendant institutional implications of industry transformation agenda are to be obtained.

This study has been limited to GFCs' perspective when conceptualising the institutional complexities and has not focused on the impact for other stakeholders such as clients and sub-contractors. Although this explicit focus might be seen as a source of limitation, there is a strength to it. This allows us to focus the attention of the discussion on this group of actors who are crucial in the implementation of any innovations that are designed to trigger widescale changes. Attempting to analyse the implications of institutional complexity arising from the transformation agenda for the multiple institutional actors would severely impair specificity in our discussion. We hope our detailed discussion with focus on GCFs inspires research on the institutional implications of industry transformation on other actors in the operating in the field and, more broadly, the construction industry.

Despite the conceptual nature of the discussion, we have critically drawn on evidence for relevant developments from government-led transformation initiatives in the UK construction industry and concepts from institutional theory to put forward research questions that, when tackled, will broaden the scope of knowledge about reform agenda. In doing so, we have provided research questions that sit at the nexus of mainstream management literature on institutional theory, industry transformation and large-scale 
changes in the construction industry. We see this as an opportunity for researchers in these three main areas to gain new insights and cross-fertilise knowledge. Micelotta et al. (2017), for instance, highlight that a comprehensive understanding of how institutional complexity faced by organisations support or hinder different kinds of institutional change is missing from the body of work on institutional theory. Some of the research questions outlined offer a direct line of enquiry to help address this gap. By putting industry transformation in the focus of institutional theory, the questions are framed to build on the works of researchers who have long championed the use of institutional theory to better understand developments in the construction industry (e.g., Dubois and Gadde, 2002; Winch, 2003).

With more governments around the world planning to or already implementing various versions of large-scale change agenda to transform their construction industries and tackle its problems, it is our hope that researchers will take up the call in this paper and explore in detail, the various facets of institutionalism that are embedded in the implementation of these policy-backed change agenda. 


\section{REFERENCES}

Bag, S., Gupta, S. and Kumar, S. (2021) 'Industry 4.0 adoption and 10R advance manufacturing capabilities for sustainable development', International Journal of Production Economics. Elsevier B.V., 231, p. 107844. doi: 10.1016/j.ijpe.2020.107844.

Barley, S. R. (2010) 'Building an Institutional Field to Corral a Government: A Case to Set an Agenda for Organization Studies', Organization Studies. SAGE PublicationsSage UK: London, England, 31(6), pp. 777-805. doi: 10.1177/0170840610372572.

Boton, C. et al. (2020) 'What is at the Root of Construction 4.0: A Systematic Review of the Recent Research Effort', Archives of Computational Methods in Engineering. Springer, 1, p. 3. doi: 10.1007/s11831-020-09457-7.

Bryden Wood \& CIH (2018) Platforms. Bridging the gap between construction+manufacturing. Available at:

https://www.cdbb.cam.ac.uk/files/platforms_bridging_the_gap_small.pdf(Accessed: 11 March 2021).

Buehler, M., Buffet, P. P. and Castagnino, S. (2018) The Fourth Industrial Revolution is about to hit the construction industry. Here's how it can thrive | World Economic Forum, WEF. Available at: https://www.weforum.org/agenda/2018/06/construction-industryfuture-scenarios-labour-technology/ (Accessed: 9 March 2021).

Cabinet Office (2011) Government Construction Strategy.

CDBB (2020) The approach to delivering a National Digital Twin for the United Kingdom Summary report.

Chan, P. W. (2020) 'Briefing: Industry 4.0 in construction: radical transformation or restricted agenda?', Proceedings of the Institution of Civil Engineers - Management, Procurement and Law. ICE Publishing, 173(4), pp. 141-144. doi: 10.1680/jmapl.20.00036.

CLC (2020) Roadmap to Recovery An Industry Recovery Plan for the UK Construction 
Sector. Available at: https://www.constructionleadershipcouncil.co.uk/wpcontent/uploads/2020/06/CLC-Roadmap-to-Recovery-01.06.20.pdf (Accessed: 11 March 2021).

Dainty, A. et al. (2017) 'BIM and the small construction firm: a critical perspective', Building Research and Information. Routledge, 45(6), pp. 696-709. doi: 10.1080/09613218.2017.1293940.

Dallasega, P., Rauch, E. and Linder, C. (2018) 'Industry 4.0 as an enabler of proximity for construction supply chains: A systematic literature review', Computers in Industry. Elsevier B.V., pp. 205-225. doi: 10.1016/j.compind.2018.03.039.

Dalpiaz, E., Rindova, V. and Ravasi, D. (2016) 'Combining Logics to Transform Organizational Agency: Blending Industry and Art at Alessi.', Administrative Science Quarterly, 61(3), pp. 347-392. doi: https://doiorg.ezp.lib.cam.ac.uk/10.1177/0001839216636103.

De'ath, M. and Farmer, M. (2020) Build Homes, Build Jobs, Build Innovation.

DiMaggio, P. J. and Powell, W. W. (1983) 'The Iron Cage Revisited: Institutional Isomorphism and Collective Rationality in Organizational Fields', American Sociological Review. SAGE Publications, 48(2), p. 147. doi: 10.2307/2095101.

Dubois, A. and Gadde, L. E. (2002) 'The construction industry as a loosely coupled system: Implications for productivity and innovation', Construction Management and Economics. Taylor \& Francis Group , 20(7), pp. 621-631. doi: 10.1080/01446190210163543.

Duong Oesterreich, T. and Teuteberg, F. (2016) 'Understanding the implications of digitisation and automation in the context of Industry 4.0: A triangulation approach and elements of a research agenda for the construction industry'. doi: 10.1016/j.compind.2016.09.006.

Egan, J. (1998) Rethinking construction, The report of the Construction Task Force. 
Ernstsen, S. N. et al. (2021) 'How Innovation Champions Frame the Future: Three Visions for Digital Transformation of Construction', Journal of Construction Engineering and Management. American Society of Civil Engineers (ASCE), 147(1), p. 05020022. doi: $10.1061 /($ asce)co.1943-7862.0001928.

Farmer, M. (2016) 'The Farmer Review of the UK Construction Labour Model', Farmer, M. (2016). Modernise or die: The Framer Review of the UK construction labour market. Retrieved from, p. 76. Available at:

https://www.gov.uk/government/publications/constructionlabour-\%0Amarket-in-the-ukfarmer-review.

Fitzgerald, M. et al. (2013) Embracing Digital Technology A New Strategic Imperative. Available at: http://sloanreview.mit.edu/faq/ (Accessed: 10 March 2021).

Frank, A. G. et al. (2019) 'Servitization and Industry 4.0 convergence in the digital transformation of product firms: A business model innovation perspective', Technological Forecasting and Social Change. Elsevier Inc., 141, pp. 341-351. doi: 10.1016/j.techfore.2019.01.014.

Frederiksen, N., Gottlieb, S. C. and Leiringer, R. (2021) 'Organising for infrastructure development programmes: Governing internal logic multiplicity across organisational spaces', International Journal of Project Management. Elsevier BV. doi: 10.1016/j.ijproman.2021.01.004.

Gann, D. M. et al. (2000) 'Innovation in project-based, service-enhanced firms: the construction of complex products and systems', Research Policy. Elsevier, 29(7-8), pp. 955-972. Available at: https://econpapers-repecorg.ezp.lib.cam.ac.uk/RePEc:eee:respol:v:29:y:2000:i:7-8:p:955-972 (Accessed: 9 March 2021).

García de Soto, B. et al. (2018) 'Productivity of digital fabrication in construction: Cost and 
time analysis of a robotically built wall', Automation in Construction. Elsevier B.V., 92, pp. 297-311. doi: 10.1016/j.autcon.2018.04.004.

Gottlieb, S. C. et al. (2020) 'Hybrid organisations as trading zones: responses to institutional complexity in the shaping of strategic partnerships', Construction Management and Economics. Routledge, 38(7), pp. 603-622. doi: 10.1080/01446193.2020.1738514.

Government, H. (2013) Construction 2025.

Government, H. (2018) Industrial Strategy Construction Sector Deal.

Government, H. (2020) The Construction Playbook: Government Guidance on sourcing and contracting public works projects and programmes.

Green, B. (2014) The Real Face of Construction A Socio-Economic Analysis of the True Value of the Built Environment. Available at: www.ciob.org (Accessed: 10 March 2021).

Green, S. (2013) 'At it again', Construction Research and Innovation. Informa UK Limited, 4(3), pp. 12-15. doi: 10.1080/20450249.2013.11873892.

Green, S. (2019) Modern methods of construction: unintended consequences. Available at: https://www.buildingsandcities.org/insights/commentaries/modern-methods-ofconstruction.html (Accessed: 11 March 2021).

Green, S. (2021) Critical Reflections on The Construction Playbook.

Greenwood, R. et al. (2011) 'Institutional complexity and organizational responses', Academy of Management Annals. Routledge , 5(1), pp. 317-371. doi: $10.1080 / 19416520.2011 .590299$.

Hackitt, J. and Freng, D. (2018) Building a Safer Future Cm 9607 Independent Review of Building Regulations and Fire Safety: Final Report. Available at: www.gov.uk/government/publications (Accessed: 10 March 2021).

Hall, D. M., Whyte, J. K. and Lessing, J. (2020) 'Mirror-breaking strategies to enable digital manufacturing in Silicon Valley construction firms: a comparative case study', 
Construction Management and Economics. Routledge, 38(4), pp. 322-339. doi:

10.1080/01446193.2019.1656814.

Hetemi, E. et al. (2020) 'The recursive interaction of institutional fields and managerial legitimation in large-scale projects', International Journal of Project Management. Elsevier Ltd. doi: 10.1016/j.ijproman.2020.11.004.

HM Government (2015) Digital Built Britain - Level 3 Strategy.

HM Government (2020) National Infrastructure Strategy - Fairer, faster, greener November 2020. Available at: www.gov.uk/official-documents (Accessed: 11 March 2021).

Homes England (2020) Introduction to the Affordable Homes Programme 2021 to 2026 GOV.UK. Available at: https://www.gov.uk/government/collections/introduction-to-theaffordable-homes-programme-2021-2026 (Accessed: 10 March 2021).

House of Lords (2018) Off-site manufacture for construction: Building for change, Oral and Written evidence Contents. Available at:

https://www.parliament.uk/globalassets/documents/lords-committees/sciencetechnology/off-site-manufacture-for-construction/off-site-manufacture-constructionev.pdf (Accessed: 11 March 2021).

Infrastructure and Projects Authorty (IPA) (2016) Government Construction Strategy 201620. Available at:

https://assets.publishing.service.gov.uk/government/uploads/system/uploads/attachment_ data/file/510354/Government_Construction_Strategy_2016-20.pdf(Accessed: 9 March 2021).

Infrastructure and Projects Authorty (IPA) (2020) Proposal for a New Approach to Building: Call for Evidence Summary of responses Infrastructure and Projects Authority. Jacobsson, S., Arnäs, P. O. and Stefansson, G. (2017) ‘Access management in intermodal 
freight transportation: An explorative study of information attributes, actors, resources and activities', Research in Transportation Business and Management. Elsevier Ltd, 23, pp. 106-124. doi: 10.1016/j.rtbm.2017.02.012.

Latham, M. (1994) CONSTRUCTING THE TEAM Joint Review of Procurement and Contractual Arrangements in the United Kingdom Construction Industry Final Report.

Laubier, R. de et al. (2019) The Offsite Revolution in Construction, BCG. Available at: https://www.bcg.com/publications/2019/offsite-revolution-construction (Accessed: 9 March 2021).

Linderoth, H. C. J. (2010) 'Understanding adoption and use of BIM as the creation of actor networks', Automation in Construction. Elsevier, 19(1), pp. 66-72. doi: 10.1016/j.autcon.2009.09.003.

Mariani, M. and Borghi, M. (2019) 'Industry 4.0: A bibliometric review of its managerial intellectual structure and potential evolution in the service industries', Technological Forecasting and Social Change. Elsevier Inc., 149. doi: 10.1016/j.techfore.2019.119752. Meyer, J. W. and Rowan, B. (1977) 'Institutionalized Organizations: Formal Structure as Myth and Ceremony', American Journal of Sociology AJS, 83(2), pp. 340-363.

Meyer, R. E. and Höllerer, M. A. (2016) 'Laying a smoke screen: Ambiguity and neutralization as strategic responses to intra-institutional complexity', Strategic Organization. SAGE Publications Ltd, 14(4), pp. 373-406. doi: $10.1177 / 1476127016633335$.

Micelotta, E., Lounsbury, M. and Greenwood, R. (2017) 'Pathways of Institutional Change: An Integrative Review and Research Agenda', Journal of Management. SAGE Publications Inc., 43(6), pp. 1885-1910. doi: 10.1177/0149206317699522. NAO (2005) Using modern methods of construction to build homes more quickly and efficiently. 
NBS (2020) 10th National BIM Report. Available at:

https://www.thenbs.com/knowledge/national-bim-report-2020 (Accessed: 10 March 2021).

NHBC (2018) Modern methods of construction Who's doing what? Available at: https://www.nhbcfoundation.org/wp-content/uploads/2018/11/NF82.pdf (Accessed: 11 March 2021).

Ocasio, W., Laamanen, T. and Vaara, E. (2018) 'Communication and attention dynamics: An attention-based view of strategic change', Strategic Management Journal. John Wiley and Sons Ltd, 39(1), pp. 155-167. doi: 10.1002/smj.2702.

Ocasio, W., Thornton, P. H. and Lounsbury, M. (2018) 'Advances to the Institutional Logics Perspective', in The SAGE Handbook of Organizational Institutionalism. 1 Oliver's Yard, 55 City Road London EC1Y 1SP : SAGE Publications Ltd, pp. 509-531. doi: 10.4135/9781446280669.n20.

Oliver, C. (1991) 'Strategic Responses to Institutional Processes', The Academy of Management Review. The Academy of Management, 16(1), p. 145. doi: 10.2307/258610. ONS (2018) Construction statistics, Great Britain - Office for National Statistics. Available at: https://www.ons.gov.uk/businessindustryandtrade/constructionindustry/articles/constructi onstatistics/2018 (Accessed: 10 March 2021).

Oti-Sarpong, K. and Burgess, G. (2020) 'Offsite Manufacturing and Construction Industry Transformation: A Multi-Level Sociotechnical Transitions Perspective', in Scott, L. and Neilson, C. J. (eds) Proceedings 36th Annual ARCOM Conference. Association of Researchers in Construction Management, pp. 475-484.

Pache, A.-C. and Santos, F. (2010) 'When Worlds Collide: The Internal Dynamics of Organizational Responses to Conflicting Institutional Demands', Academy of 
Management Review. Academy of Management, 35(3), pp. 455-476. doi: 10.5465/amr.35.3.zok455.

Pache, A. C. and Santos, F. (2013) 'Inside the hybrid organization: Selective coupling as a response to competing institutional logics', Academy of Management Journal. Academy of Management Briarcliff Manor, NY , 56(4), pp. 972-1001. doi: 10.5465/amj.2011.0405.

Pasetti Monizza, G., Bendetti, C. and Matt, D. T. (2018) 'Parametric and Generative Design techniques in mass-production environments as effective enablers of Industry 4.0 approaches in the Building Industry', Automation in Construction. Elsevier B.V., 92, pp. 270-285. doi: 10.1016/j.autcon.2018.02.027.

du Plessis, C. and Sherratt, F. (2020) 'Construction 4.0 and built assets in-use: creating an etopia or dystopia?', Proceedings of the Institution of Civil Engineers - Management, Procurement and Law. ICE Publishing, 173(4), pp. 182-189. doi: 10.1680/jmapl.19.00054.

Rasmussen, G. M. G., Jensen, P. L. and Gottlieb, S. C. (2017) 'Frames, agency and institutional change: the case of benchmarking in Danish construction', Construction Management and Economics. Routledge, 35(6), pp. 305-323. doi: 10.1080/01446193.2017.1298824.

Raynard, M. and Greenwood, R. (2014) 'Deconstructing complexity: How organizations cope with multiple institutional logics', in 74th Annual Meeting of the Academy of Management, AOM 2014. Academy of Management, pp. 735-740. doi: 10.5465/AMBPP.2014.132.

Reischauer, G. (2018) 'Industry 4.0 as policy-driven discourse to institutionalize innovation systems in manufacturing', Technological Forecasting and Social Change. Elsevier Inc., 132, pp. 26-33. doi: 10.1016/j.techfore.2018.02.012. 
Ribeirinho, M. J. et al. (2020) 'The next normal in construction', Mckinsey \& Company, (June), p. 84.

Sawhney, A., Riley, Mike and Irizarry, J. (2020) Construction 4.0. Edited by A. Sawhney, Michael Riley, and J. Irizarry. Routledge. doi: 10.1201/9780429398100.

Scott, W. R. (2004) 'Institutional Theory: Contributing to a Theoretical Research Program', in Great Minds in Management: The Process of Theory Development. Available at: https://www.researchgate.net/publication/265348080 (Accessed: 10 March 2021).

Sergeeva, N. and Winch, G. M. (2020) 'Narrative interactions: How project-based firms respond to Government narratives of innovation', International Journal of Project Management. Elsevier Ltd, 38(6), pp. 379-387. doi: 10.1016/j.ijproman.2020.08.005.

Tee, R., Davies, A. and Whyte, J. (2019) 'Modular designs and integrating practices: Managing collaboration through coordination and cooperation', Research Policy. Elsevier B.V., 48(1), pp. 51-61. doi: 10.1016/j.respol.2018.07.017.

Thornton, P. H. and Ocasio, W. (2008) 'Institutional Logics', in The SAGE Handbook of Organizational Institutionalism. 1 Oliver's Yard, 55 City Road, London EC1Y 1SP United Kingdom: SAGE Publications Ltd, pp. 99-128. doi: 10.4135/9781849200387.n4. Thornton, P. H., Ocasio, W. and Lounsbury, M. (2013) The Institutional Logics Perspective, The Institutional Logics Perspective. Oxford University Press. doi: 10.1093/acprof:oso/9780199601936.001.0001.

Vermeulen, P. et al. (2007) 'The Impact of Governmental Policies in Institutional Fields: The Case of Innovation in the Dutch Concrete Industry', Organization Studies. Sage PublicationsSage UK: London, England, 28(4), pp. 515-540. doi: 10.1177/0170840606067927.

Whyte, J. (2019) 'How Digital Information Transforms Project Delivery Models', Project Management Journal. SAGE Publications Inc., 50(2), pp. 177-194. doi: 


\section{$10.1177 / 8756972818823304$.}

Winch, G. (1998) 'Zephyrs of creative destruction: Understanding the management of innovation in construction', Building Research and Information. Routledge, 26(5), pp. 268-279. doi: 10.1080/096132198369751.

Winch, G. M. (2000) ‘The Management of Projects as a Generic Business Process’, in Projects as Business Constituents and Guiding Motives. Springer US, pp. 117-130. doi: 10.1007/978-1-4615-4505-7_9.

Winch, G. M. (2001) 'Governing the project process: A conceptual framework', Construction Management and Economics. Taylor \& Francis Group , 19(8), pp. 799-808. doi: $10.1080 / 01446190110074264$.

Winch, G. M. (2003) 'Models of manufacturing and the construction process: The genesis of re-engineering construction', Building Research and Information. Taylor \& Francis Group , 31(2), pp. 107-118. doi: 10.1080/09613210301995.

Winch, G. M. and Maytorena-Sanchez, E. (2020) 'Institutional projects and contradictory logics: Responding to complexity in institutional field change', International Journal of Project Management. Elsevier Ltd, 38(6), pp. 368-378. doi: 10.1016/j.ijproman.2020.08.004.

Wolstenholme, A. (2009) Never Waste a Good Crisis A Review of Progress since Rethinking Construction and Thoughts for Our Future.

Xu, L. Da, Xu, E. L. and Li, L. (2018) 'Industry 4.0: State of the art and future trends', International Journal of Production Research. Taylor and Francis Ltd., 56(8), pp. 29412962. doi: $10.1080 / 00207543.2018 .1444806$.

Yoo, Y. et al. (2012) 'Organizing for innovation in the digitized world', Organization Science. INFORMS , 23(5), pp. 1398-1408. doi: 10.1287/orsc.1120.0771.

Zomer, T. et al. (2020) 'Exploring the influence of socio-historical constructs on BIM 
implementation: an activity theory perspective', Construction Management and Economics. Routledge, pp. 1-20. doi: 10.1080/01446193.2020.1792522. 
4.

4. 它

- loT

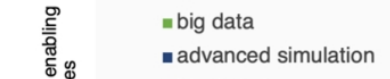

3.

-blockchain

을 들 $\quad=B I M$,

कrobotics

- BIM mandate

- construction sector deal

2

- cabinet office release

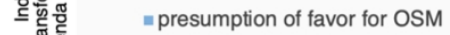

- platform approach

- lending facilities

- demand for assets

1. 离 =inflation

- financial cycles

क्षे $\quad$ insurance

- social acceptance

- legal framework 
Table 1: Evidence of Government focus areas on construction industry transformation

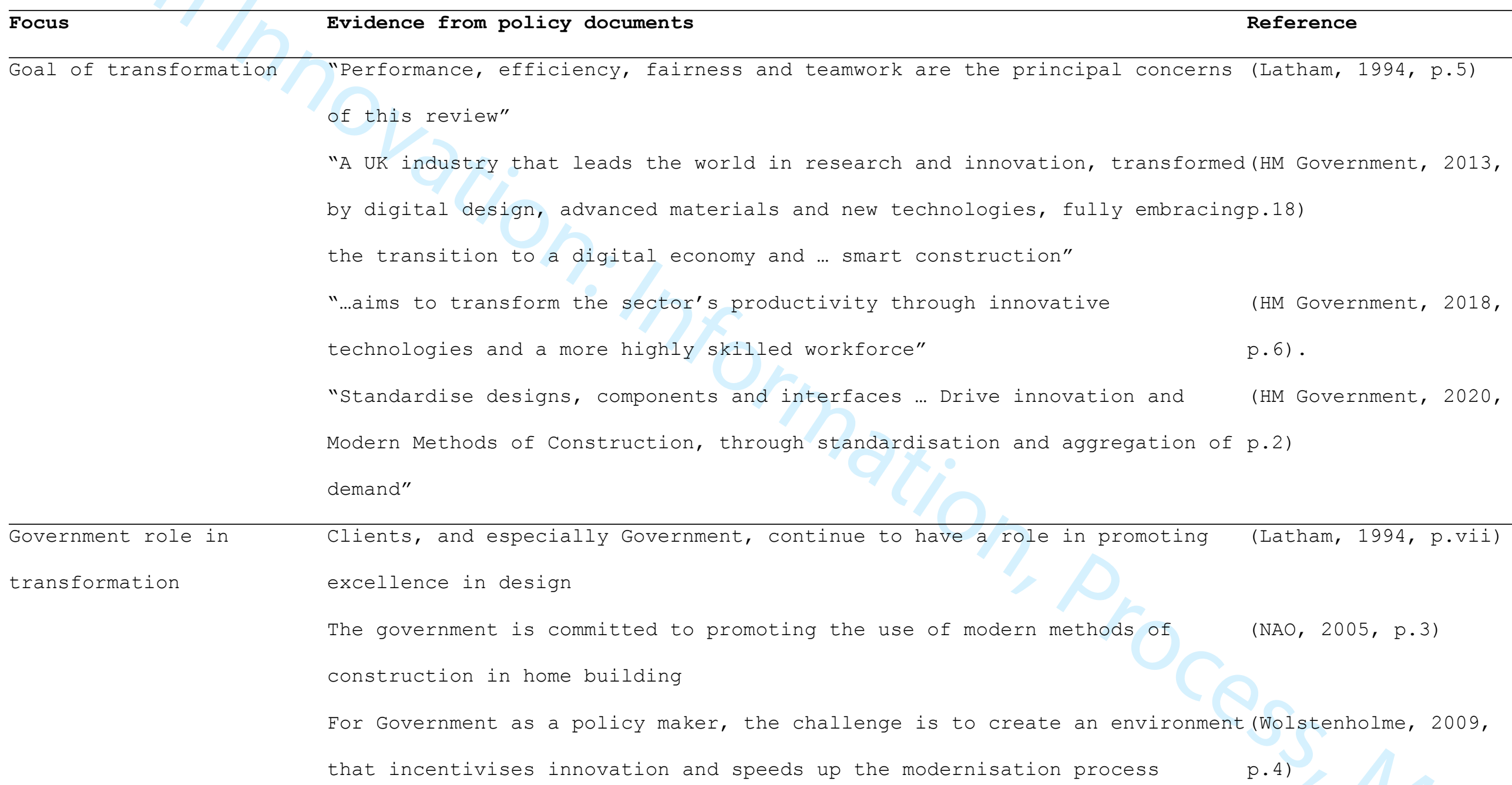


"The government will seek to deliver construction projects more

efficiently, including through Building Information Modelling (BIM) and

improved insight into construction data"

"The government has ...set out its requirement for fully collaborative 3D BIM(IPA, 2016 , p.104).

on centrally procured government construction projects by 2016 . ... The

government will develop the next digital standard for the construction sector"

"Facilitate the adoption of Modern Methods of Construction (MMC), off-site (HM Government, 2020, manufacturing ... embed digital technologies ... and to support... creation of p.86) the National Digital Twin"

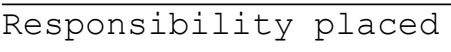

on supplier network

actors

\section{Supply chains need to work more efficiently. Long-term collaborative}

working should be promoted with earlier involvement on projects, not only

main contractors, but also specialists and suppliers
(Wolstenholme, 2009,

p.31) .

3.

33

"Industry must therefore meet the challenge ... through the implementation of (HM Government, 2013 , BIM ... able to deliver more sustainable buildings, more quickly and more p.9). efficiently" 
"The government can use its weight as a major construction client to

(HM Treasury, 2020, p.86)

transform and modernise the industry"

"The proposed strategy of P-DfMA ...seeks to leverage government buying power(IPA, 2019, p.4)

to accelerate innovate and the adoption of industry best practice"

Prioritisation of ICT,

"... common standards for the exchange of electronic data would be highly

(Latham, 1994, p.25).

Data centricity and

desirable"

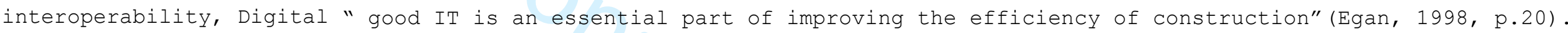

technologies and Digital "There are enormous benefits to be gained, in terms of eliminating waste (Egan, 1998, p.28)

Twins

and rework for example, from using modern CAD technology to prototype

buildings and by rapidly exchanging information on design changes"

"The Cabinet Office will co-ordinate Government's drive to the development (Cabinet office, 2011,

of standards enabling all members of the supply chain to work

collaboratively through Building Information Modelling (BIM)"

"Government will require fully collaborative 3D BIM ...as a minimum by 2016" (Cabinet Office, 2011, p.14)

"By 2016 all Government construction projects will be using BIM level 2, (HM Government, 2013 , irrespective of project size. Between 2016 and 2025 it is expected that thep.60).

UK Government and industry will move to Level 3 BIM" 


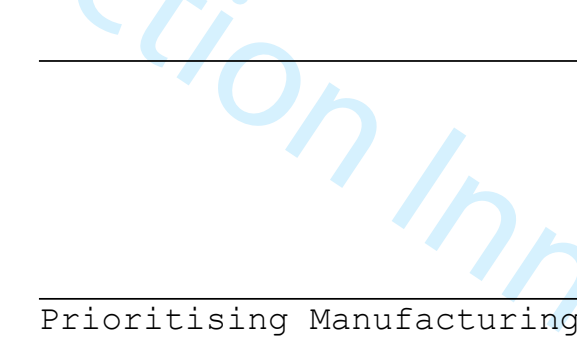

"Digital Built Britain strategy takes the next step in integrating these

(HM Government, 2015, technologies...We want to make fully computerized construction the norm and p.5).

ensure that the benefits of these technologies are felt across the UK"

作

$($ Egan, 1998, p.27)

use of interoperable

standardised components concept of "design for construction"

"Greater emphasis should be placed on off-site manufacture and development (Wolstenholme, 2009, of standardised products"

"... using an arrangement that will enable/encourage (but not prescribe) (Cabinet Office, 2011, appropriate standardisation,... offsite fabrication of buildings, systems or p.16) components"

"Develop digital building designs for use in procurement for infrastructure (HM Government, 2018 , projects. The Education \& Skills Funding Agency (ESFA) to work to develop ap.13)

product platform for new school buildings..."

"... (the Ministry of Justice, Department of Health and Social Care, $(I P A, 2019$, p.1) Department for Education, Department for Transport and Ministry of Defence) would adopt a presumption in favour of offsite construction" 
"Fully implement presumption of offsite, and seek to increase the number of (CLC, 2020, p.18) projects making use of these and the proportion of pre-manufactured value within these projecto

within these projects (HMG/public sector clients)"

"Private sector clients to seek to increase the use of offsite

manufacturing in the delivery of homes and commercial construction

projects, utilising the outputs of the Transforming Construction Challenge,

including the development of product platforms for built assets (Industry)" 
Table 2: Summary of defining features of the UK construction industry transformation agenda through Oliver's (1991) framework

\begin{tabular}{|c|c|}
\hline Feature & Defining characteristics \\
\hline Cause & $\begin{array}{l}\text { Creation of an efficient and productive sector to reduce project } \\
\text { delivery and operating costs, produce energy efficient assets and }\end{array}$ \\
\hline Content & $\begin{array}{l}\text { Adoption of different digital, manufacturing and platform } \\
\text { technologies linked to other cyber-physical systems technologies to } \\
\text { change industry practices (e.g., procurement, (inter) organisational } \\
\text { practices for project design, construction and asset management). }\end{array}$ \\
\hline Referents & $\begin{array}{l}\text { Multiple constituents - Government, public sector clients and arms- } \\
\text { length bodies, private clients, public procurement entities, several } \\
\text { regulators - making varied demands which GCFs need to respond. } \\
\text { Strong resource dependence mainly between GCFs and clients. }\end{array}$ \\
\hline Control & $\begin{array}{l}\text { Mixed control measures: coercive/obligatory (mandates; procurement } \\
\text { requirements) and voluntary diffusion measures. Moderate coercive } \\
\text { measures (BIM mandate and OSM presumption in favour for OSM) } \\
\text { currently in use. High voluntary diffusion mechanism (bottom-up } \\
\text { initiatives) encouraged. }\end{array}$ \\
\hline Context & $\begin{array}{l}\text { Characterised by very high uncertainty and very low } \\
\text { interconnectedness because the industry is fragmented }\end{array}$ \\
\hline
\end{tabular}

